\title{
Comparison of bacterial diversity and abundance between sexes of Leptocybe invasa Fisher \& La Salle (Hymenoptera: Eulophidae) from China
}

\author{
Chunhui Guo $^{1}$, Xin Peng ${ }^{1}$, Xialin Zheng ${ }^{2}$, Xiaoyun Wang ${ }^{2}$, Ruirui Wang ${ }^{1}$, Zongyou Huang ${ }^{2}$, Zhende Yang $^{\text {Corresp. }}$, $3^{3}$ \\ ${ }^{1}$ College of Forestry, Guangxi University, Nanning, Guangxi, China \\ 2 Guangxi Key Laboratory of Agric-Environment and Agric-Products Safety, College of Agriculture, Guangxi University, Nanning, Guangxi, China \\ 3 Guangxi Key Laboratory of Forest Ecology and Conservation, College of Forestry, Guangxi University, Nanning, Guangxi, China \\ Corresponding Author: Zhende Yang \\ Email address: dzyang68@126.com
}

Background. Insects harbor a myriad of microorganisms, many of which can affect the sex ratio and manipulate the reproduction of the host. Leptocybe invasa is an invasive pest that causes serious damage to eucalyptus plantations, and the thelytokous parthenogenesis, low temperature resistance, protection in galls, generation overlap and small body of $L$. invasa contribute to its rapid invasion and population growth. However, the endosymbiotic bacterial composition, abundance and sex differences of $L$. invasa remain unclear. Therefore, this research aimed to identify the bacterial communities in $L$. invasa adults and compare them between the sexes of $L$. invasa lineage $B$

Results. The Illumina MiSeq platform was used to compare bacterial community composition between females and males of $L$. invasa by sequencing the V3-V4 region of the $16 \mathrm{~S}$ ribosomal RNA gene. A total of 1320 operational taxonomic units (OTUs) were obtained. These OTUs were subdivided into 24 phyla, 71 classes, 130 orders, 245 families and 501 genera. At the genus level, the dominant bacteria in females and males were Rickettsia and Rhizobium, respectively.

Conclusion. The endosymbiotic bacteria of $L$. invasa females and males were highly diverse. There were differences in the bacterial community of $L$. invasa between sexes, and the bacterial diversity in male specimens was greater than that in female specimens. This study presents a comprehensive comparison of bacterial communities in L. invasa and these data will provide an overall view of the bacterial community in both sexes of $L$. invasa with special attention on sex-related bacteria. 


\section{Comparison of bacterial diversity and abundance between}

2 sexes of Leptocybe invasa Fisher \& La Salle (Hymenoptera:

\section{Eulophidae) from China}

4 Chunhui Guo ${ }^{1}$, Xin Peng ${ }^{1}$, Xialin Zheng ${ }^{2}$, Xiaoyun Wang ${ }^{2}$, Ruirui Wang ${ }^{1}$, Zongyou Huang ${ }^{2}$, Zhende Yang ${ }^{1,3}$

5

$6{ }^{1}$ College of Forestry, Guangxi University, Nanning, Guangxi, China

$7{ }^{2}$ Guangxi Key Laboratory of Agric-Environment and Agric-Products Safety, College of Agriculture,

8 Guangxi University, Nanning, Guangxi, China

$9{ }^{3}$ Guangxi Key Laboratory of Forest Ecology and Conservation, College of Forestry, Guangxi University,

10 Nanning, Guangxi, China

12 Corresponding Author:

13 Zhende Yang ${ }^{1,3}$

14 Daxuedong Street, Nanning, Guangxi, 530004, China

15 E-mail address: dzyang68@126.com 


\section{Comparison of bacterial diversity and abundance 17 between sexes of Leptocybe invasa Fisher \& La Salle 18 (Hymenoptera: Eulophidae) from China}

20 Chunhui Guo ${ }^{1}$, Xin Peng ${ }^{1}$, Xialin Zheng ${ }^{2}$, Xiaoyun Wang ${ }^{2}$, Ruirui Wang ${ }^{1}$, Zongyou Huang ${ }^{2}$, 21 Zhende Yang 1,3

$23{ }^{1}$ College of Forestry, Guangxi University, Nanning, Guangxi, China

$24{ }^{2}$ Guangxi Key Laboratory of Agric-Environment and Agric-Products Safety, College of

25 Agriculture, Guangxi University, Nanning, Guangxi, China

$26{ }^{3}$ Guangxi Key Laboratory of Forest Ecology and Conservation, College of Forestry, Guangxi

27 University, Nanning, Guangxi, China

29 Corresponding Author:

30 Zhende Yang ${ }^{1,3}$

31 Daxuedong Street, Nanning, Guangxi, 530004, China

32 E-mail address: dzyang68@126.com 


\section{Abstract}

35 Background. Insects harbor a myriad of microorganisms, many of which can affect the sex ratio 36 and manipulate the reproduction of the host. Leptocybe invasa is an invasive pest that causes 37 serious damage to eucalyptus plantations, and the thelytokous parthenogenesis, low temperature 38 resistance, protection in galls, generation overlap and small body of $L$. invasa contribute to its 39 rapid invasion and population growth. However, the endosymbiotic bacterial composition, 40 abundance and sex differences of $L$. invasa remain unclear. Therefore, this research aimed to

41 identify the bacterial communities in $L$. invasa adults and compare them between the sexes of $L$. 42 invasa lineage $\mathrm{B}$.

43 Results. The Illumina MiSeq platform was used to compare bacterial community composition 44 between females and males of $L$. invasa by sequencing the V3-V4 region of the $16 \mathrm{~S}$ ribosomal 45 RNA gene. A total of 1320 operational taxonomic units (OTUs) were obtained. These OTUs 46 were subdivided into 24 phyla, 71 classes, 130 orders, 245 families and 501 genera. At the genus 47 level, the dominant bacteria in females and males were Rickettsia and Rhizobium, respectively. 48 Conclusion. The endosymbiotic bacteria of $L$. invasa females and males were highly diverse.

49 There were differences in the bacterial community of $L$. invasa between sexes, and the bacterial diversity in male specimens was greater than that in female specimens. This study presents a comprehensive comparison of bacterial communities in L. invasa and these data will provide an

52 overall view of the bacterial community in both sexes of $L$. invasa with special attention on sex53 related bacteria. 


\section{Introduction}

55 There are numerous microorganisms living in insects, including bacteria, fungi, yeast and viruses, 56 that play a vital role in the growth and reproduction of host insects (Dillon \& Dillon, 2004; Doğanlar, 2005; Crotti et al., 2012; Frago et al., 2012; Engel \& Moran, 2013; Hammer \& Bowers, 2015). Over the course of long-term coevolution, microorganisms develop a close relationship with host insects, which may have an effect on the reproduction, survival, community interactions, and the ability to resist predators and vectors of the hosts (Oliver et al., 2003, 2010; Moran, 2007; Clark et al., 2008; Moran et al., 2008; Moya et al., 2008). In light of the significant functions of the microorganisms, they have received much attention from the international academic community. In some insects, the diversity and function of endosymbiotic bacteria have been well studied. For instance, the bacteria in termites are mainly Bacteroidetes, Firmicutes and Actinobacteria and can assist their hosts in breaking down lignocellulose and promoting the nitrogen cycle (Warnecke et al., 2007; Brune, 2014). The bacteria in Aphis gossypii improve its resistance and adaptation (Eukasik et al., 2013a, b). In recent years, manipulating endosymbionts for pest control has raised wide concern, and its theory and methods have been applied successfully to some extent. Introduction of antimalarial endosymbionts into the mid gut of host pests could inhibit the breeding of plasmodia and in turn reduce the efficiency of mosquito transmission of malaria (Wang et al., 2012). Mixed application of antibiotics and insecticides effectively reduced the quantity of endosymbionts in Nilaparvata lugens while improving the control effect of insecticides (Shentu et al., 2016). Based on research on the related incompatible insect technique (IIT), researchers used the maternally inherited endosymbiotic bacterium Wolbachia for sterilization, which had good effects on eliminating the fecundity of mosquitoes (Zheng et al., 2019). Obviously, it is necessary to clarify the bacterial composition and diversity in insects, which are the bases of manipulating endosymbionts for pest control. In addition, previous investigations have shown that sex is an important factor affecting bacterial diversity. For example, due to different attack behaviors, the overall diversity and richness of bacterial communities associated with female Dendroctonus valens are higher than those associated with males of this beetle species (Xu et al., 2016). The bacterial composition of mosquitoes was also affected by sex (Minard et al., 2013; Zouache et al., 2011). Different anatomies and life histories between male and female flies could provide differential

84 opportunities for bacterial colonization (Tang et al., 2012). 
85

86

87

88

89

90

91

92

93

94

95

96

97

98

99

100

101

102

103

104

105

106

107

108

109

110

111

112

113

114

115 Nugnes et al., 2015). Therefore, the overall endosymbiotic bacterial composition and abundance

The blue gum chalcid Leptocybe invasa Fisher \& LaSalle (Hymenoptera: Eulophidae: Tetrastichinae) is a cosmopolitan pest that damages many Eucalyptus species (Mendel et al., 2004; Le et al., 2018). L. invasa, originating in Australia, was first recorded in 2000 and has since been discovered in 45 countries of Asia, Europe, Africa, Oceania and America (Le et al., 2018; Zheng et al., 2014a). A new study demonstrated that an increasing number of areas will become suitable for L. invasa due to climate warming (Huang et al., 2019). Every delicate twig, vein and petiole of eucalyptus trees may provide a spawning ground for this pest, and galls ultimately lead to stunted growth of the trees, causing great losses in local eucalyptus plantations (Mendel et al., 2004; Zheng et al., 2014a; Huang et al., 2018). DNA barcode data indicated that L. invasa includes two genetically separate lineages (lineages A and B). Researchers considered the Italian, Argentinean and Tunisian populations to belong to lineage A and the Chinese population to belong to lineage B (Le et al., 2018; Dittrich-Schröder et al., 2018). The absence of natural enemies, presence of large amounts of suitable host plants, small size, protection in galls, strong resistance to low temperature and thelytokous parthenogenesis of L. invasa caused its rapid invasion and growth of in China (Zheng et al., 2014a). As a result, it has become one of the most difficult pests to control (Zheng et al., 2014a; Huang et al., 2018; Le et al., 2018). It is important in tems of theory and application to study the endosymbiotic bacterial diversity of $L$. invasa and then control the wasps by using these endosymbiotic bacteria.

To date, few studies have reported on the overall endosymbiotic bacteria of L. invasa, which is an invasive gall-inducing insect. Only a few studies have comprehensively examined the endosymbiotic bacteria in this species. Wang et al. (2018) cultured 11 strains from female adults of $L$. invasa in winter using traditional methods and classified them into 3 phyla (Firmicutes, Actinobacteria, and Proteobacteria), 3 classes (Bacilli, Actinobacteria, and Gammaproteobacteria) and 4 orders (Bacillales, Micrococcales, Lactobacillales, and Enterobacterales) that were related to growth, development, nutrition metabolism and immunity. Nugnes et al. (2015) researched the bacteria living in adults among different populationsvia denaturing gradient gel electrophoresis (DGGE) analysis and found that Rickettsia occurred in the reproductive tissues of female L. invasa, suggesting a relationship with its thelytokous parthenogenesis. L. invasa harbors a myriad of bacteria, and bacterial differences between sexes have strong effects on insects, such as effects on reproductive regulation (Wang et al., 2018; 
116 of L. invasa and the differences between sexes are important to study.

117 In this study, the endosymbiotic bacteria in female and male adults of L. invasa were

118 indentified by $16 \mathrm{~S}$ rRNA sequencing of the V3-V4 region to shed light on their internal bacterial

119 compositions. The females and males were also compared to address sexual differences in the

120 endosymbionts. These results will provide a valuable bacterial pool for L. invasa and will further

121 contribute to understanding its reproductive strategies and invasion mechanisms.

\section{Materials \& Methods}

123 Insect sampling

124 Branches of DH 201-2 (Eucalyptus grandis $\times$ E. tereticornis) (Myrtales: Myrtaceae) harboring 125 galls of L. invasa were removed from the Teaching and Experiment Base of Forestry College, 126 Guangxi University (108 $17^{\prime}$ E, 22 $\left.2^{\circ} 1^{\prime} \mathrm{N}\right)$, Nanning city, Guangxi Zhuang Autonomous Region

127 from July to August 2018. The branches were placed in a plastic bottle filled with water to retain

128 freshness and transferred into a sealed net cage $(40 \mathrm{~cm} \times 40 \mathrm{~cm} \times 80 \mathrm{~cm})$ at room temperature to

129 keep the adults from escaping. The water in the plastic bottle was renewed daily until the

130 emergence of L. invasa adults. Sexes were identified by morphological observation (Zheng et al., $1312014 b)$.

\section{DNA extraction}

133 Fifty adults of each sex of L. invasa newly emerged within $12 \mathrm{~h}$ were fasted for $6 \mathrm{~h}$. Then, both 134 samples were sterilized externally with $75 \%$ ethanol for $2-5$ min and rinsed 3 times with 135 sterilized water to remove microbes on the surface. The total bacterial DNA of each sample was 136 extracted using a Power Soil DNA Isolation Kit (MO BIO Laboratories) according to the 137 manufacturer's instructions. The quality and quantity of DNA were assessed by the ratios of 260 $138 \mathrm{~nm} / 280 \mathrm{~nm}$ and $260 \mathrm{~nm} / 230 \mathrm{~nm}$. Then, the qualified DNA was stored at $-80{ }^{\circ} \mathrm{C}$ for further 139 processing. The DNA of each individual was extracted by using a Chelex-100 and proteinase K140 based method (Gebiola et al., 2009).

\section{PCR amplification and cloning of the bacterial 16S rRNA gene}

142 Amplification of the V3-V4 hypervariable region of the bacterial 16S rRNA gene was performed 143 by using the universal bacterial primers 338F (5'-ACTCCTACGGGAGGCAGCA-3') and 806R

144 (5'- GACTACHVGGGTWTCTAAT-3'). PCRs were carried out in $50 \mu \mathrm{L}$ solutions containing 10 $145 \mu \mathrm{L}$ of $10 \times$ buffer, $0.2 \mu \mathrm{L}$ of Q5 High-Fidelity DNA Polymerase, $10 \mu \mathrm{L}$ of High GC Enhancer, 1 $146 \mu \mathrm{L}$ of dNTPs, $10 \mu \mathrm{M}$ each forward and reverse primer, $60 \mathrm{ng}$ of genomic DNA and enough 
$147 \mathrm{ddH}_{2} \mathrm{O}$ to reach $50 \mu \mathrm{L}$. The amplifications were performed in a ABI Applied Biosystems 9902

148 thermal cycler with an initial denaturation step at $95{ }^{\circ} \mathrm{C}$ for $5 \mathrm{~min}$, followed by 35 cycles of

149 annealing and extension (each cycle consisted of $95^{\circ} \mathrm{C}$ for $1 \mathrm{~min}, 50{ }^{\circ} \mathrm{C}$ for $1 \mathrm{~min}$ and extension

150 at $72{ }^{\circ} \mathrm{C}$ for $1 \mathrm{~min}$ ) and a final extension at $72^{\circ} \mathrm{C}$ for $7 \mathrm{~min}$. The PCR products were checked by

151 electrophoresis on an agarose gel $(1.8 \%$ agarose, $1 \times \mathrm{TBE})$, stained with ethidium bromide and

152 visualized under ultraviolet light. The products from the first round of PCR were purified with

153 VAHTS ${ }^{\mathrm{TM} M}$ DNA Clean Beads. The second round of PCR was then performed in a $40 \mu \mathrm{L}$

154 reaction containing $20 \mu \mathrm{L}$ of $2 \times \mathrm{Ph} \mu$ sion $\mathrm{HF}$ MM, $8 \mu \mathrm{L}$ of $\mathrm{ddH}_{2} \mathrm{O}, 10 \mu \mathrm{M}$ each forward and

155 reverse primer and $10 \mu \mathrm{L}$ of PCR product produced in the first round. The second round of PCR

156 was run under the following conditions: initial denaturation at $98{ }^{\circ} \mathrm{C}$ for $30 \mathrm{~s}$, followed by 10

157 cycles at $98{ }^{\circ} \mathrm{C}$ for $10 \mathrm{~s}, 65^{\circ} \mathrm{C}$ for $30 \mathrm{~s}$ and $72{ }^{\circ} \mathrm{C}$ for $30 \mathrm{~s}$ and a final extension at $72{ }^{\circ} \mathrm{C}$ for $5 \mathrm{~min}$.

158 Finally, all PCR products were quantified and pooled by Quant-iT ${ }^{\mathrm{TM}}$ dsDNA HS Reagent. High-

159 throughput sequencing analysis of bacterial rRNA genes was performed on the purified, pooled

160 sample by using the Illumina HiSeq 2500 platform at Biomarker Technologies Co., Ltd, Beijing,

161 China.

\section{Bioinformatics and statistical analysis}

163 After sequencing, PE reads obtained with HiSeq sequencing were merged by overlapping to

164 obtain raw tags. To obtain clean tags, the raw tags were denoised, sorted and separated by using

165 Trimmomatic (version 0.33). The remaining sequences were filtered for redundancy, and all

166 unique sequences in each sample were clustered into operational taxonomic units (OTUs) on the

167 basis of $97 \%$ similarity. Low-abundance OTUs were identified and eliminated by using

168 UCHIME v4.2. Taxonomic assignment of the OTUs was conducted with the Silva reference

169 database. Species abundance tables were generated by QIIME, and community structures in

170 every taxon category was plotted by R software. The relative abundances of the bacteria were

171 determined by percentages.

172 Alpha diversity based on Chao1 richness and ACE richness estimators, as well as the

173 Simpson and Shannon diversity indices, was evaluated by using the mothur v.1.11.0 program.

174 Among these measure, Chaol and ACE reflected species richness in the samples, the Shannon

175 index reflected community diversity, the Simpson index reflected the dominance of species in

176 the community, and the coverage index reflected the degree to which the sequencing results

177 represented the actual composition of the microorganisms in the samples. 
178 Molecular characterization and phylogenetic analyses

179 COI was amplified by using the forward primer LCO1490 and reverse primer HCO2198

180 (Nugnes et al., 2015). The 16S rRNA gene of Rickettsia was amplified by using the primers

181 listed in Table S1. The PCR program for both genes (COI and 16S rRNA) was as follows: 3

182 min of initial denaturation at $94{ }^{\circ} \mathrm{C}, 30$ cycles at $94{ }^{\circ} \mathrm{C}$ for $30 \mathrm{~s}, 55^{\circ} \mathrm{C}$ for $30 \mathrm{~s}$ and $72{ }^{\circ} \mathrm{C}$ for 1

$183 \mathrm{~min}$ and a final extension of $5 \mathrm{~min}$ at $72{ }^{\circ} \mathrm{C}$. PCR products were observed by using $1.0 \%$

184 agarose gel electrophoresis, and the amplified fragments were directly sequenced by

185 TsingKe Biological Technology Co., Ltd, Beijing, China. Representative sequences of other

186 regions were downloaded from GenBank, and sequence alignment was completed by using

187 Clustal X. The neighbour-joining method was used to construct a consensus phylogenetic

188 tree with MEGA7 software. To evaluate the branch support of the phylogenetic tree,

189 bootstrap analysis of 1000 replicates was performed.

190 Accession numbers

191 Data is available at NCBI SRA, accession numbers: SRR9591039, SRR9591038. The COI and

192 16S rRNA sequences determined in this study have been deposited in the GenBank database

193 with Accession number MN524231 and MN524230, respectively.

\section{Results}

\section{Sex of $L$. invasa specimens in this study}

196 All female and male specimens were identified on the basis of morphology. In this study, a total

197 of 656 females and 51 males were collected (Table S2). The materials were deposited at the

198 Forest Conservation Laboratory, College of Forestry, Guangxi University, Nanning 530004,

199 China.

200 Sequencing and classification

201 A total of 533266 raw tags (370680 from males and 162586 from females) were obtained for $L$.

202 invasa, and 476235 clean tags (328833 from males and 147402 from females) were generated

203 (Table S3), which were classified into different OTUs based on 97\% similarity. Among the

204476235 clean tags, a total of 1320 OTUs were obtained; of these 1320 OTUs, 154 were common

205 to both sexes, and 38 and 1128 were specific to female and male adults, respectively (Fig. 1).

206 Analysis of Alpha diversity

207 Alpha diversity was estimated by five indices: Chao1, the Shannon index, the Simpson index, the

208 ACE and coverage. The results in Table 1 show that the bacteria in L. invasa adults were diverse 
209 in both sexes. The Chaol (229.50 vs 1282.00) and ACE (212.84 vs 1282.28) values were lower

210 in the females than in the males. Good agreement was also observed between the Simpson and

211 Shannon indices. The Shannon index (0.59 vs 6.13) was lower in the females than in the males,

212 while the Simpson index (0.85 vs 0.01$)$ was higher in the female wasps than in the male wasps,

213 indicating that the diversity of the bacterial community in males was higher than that in females.

214 The coverage was near $100 \%$ for both males and females, illustrating a higher probability of

215 bacteria being detected than of bacteria being undetected.

216 The analysis of community composition and species abundance

217 The bacterial community composition and species abundance in both sexes of L. invasa were

218 analyzed (abundances greater than $0.1 \%$ ) based on the results of the OTUs (Table 2, Fig. 2). A

219 total of 24 phyla were detected and classified in the samples. Proteobacteria was the dominant

220 bacterial phylum annotated in females and males, accounting for $95.63 \%$ and $34.99 \%$ of bacteria,

221 respectively. At the genus level, Rickettsia (with an abundance of 93.67\%) and Rhizobium (with

222 an abundance of 5.73\%) were the dominant bacteria in females and males, respectively. In

223 addition, it was noteworthy that the abundance of Rickettsia was less than 1\% in males (Table 3).

224 Molecular characterization and phylogenetic analyses

225 After comparison with Genebank, the identification of L.invasa in this research was lineage B

226 and the phylogenetic tree of COI also indicated that the population of this research belonged to

227 the lineage (Fig. 3). The phylogenetic analysis of 16S rRNA genes revealed that the Rickettsia of

228 L.invasa symbionts belonged to the Rickettsia transitional group (Fig. 4).

229 Discussion

230 Differences in bacteria between female and male adults

231 This research revealed that the bacteria harbored in L. invasa had high diversity, and many of the

232 endosymbiotic bacteria were annotated in this species for the first time. Based on alpha diversity

233 analysis, the diversity of the endosymbiotic bacteria in males was higher than that in females

234 (Table 1). The variation in bacterial communities between males and females may be partly

235 explained by differences in physiology structure and between the two sexes of L. invasa;

236 specifically, the female wasps have ovaries, which harbor an abundance of Rickettsia, allowing

237 the genus to occupy different bacterial niches than in males (Nugnes et al., 2015). Another

238 possibility is that insects launch innate and systematic immune responses to cope with microbe

239 colonization (Leulier \& Royet, 2009) and females have stronger immune systems than males 
240 (Kurtz et al., 2000).

\section{Comparison of the bacteria with those in other insects}

242 Bacterial community analysis at the phylum level demonstrated that Proteobacteria was the 243 dominant group in female and male wasps, and Firmicutes, Bacteroidetes, Actinobacteria and

244 Fusobacteria were also annotated. Previous studies revealed that Proteobacteria were dominant

245 in other Hymenoptera, such as Apis cerana and leaf-cutter ants (Ahn et al., 2012; Zhukova et al., 246 2017) In contrast, Firmicutes and Bacteroidetes were the major bacterial phyla detected in the 247 guts of termites (Miyata et al., 2007; Xiang et al., 2012) and bees (Mohr \& Tebbe, 2006).

248 Firmicutes and Actinobacteria were the dominant bacteria in A. mellifera and bumblebees (Ahn 249 et al., 2012; Praet et al., 2018).

\section{Putative Functions of dominant endosymbiotic bacteria in $L$. invasa}

251 Several of the bacteria detected in this study are commonly described in insects at the genus level, 252 and some have been found in Hymenoptera, such as honeybees (Mohr \& Tebbe, 2006) and 253 termites (Xiang et al., 2012). Intriguingly, two genera, Staphylococcus and Escherichia, are 254 known to contain cultivable species (Wang et al., 2018). Gloverin and lysozyme gene expression 255 was upregulated when silkworm larvae were fed Escherichia and Staphylococcus, indicating that 256 the two bacteria were closely related to the immune signaling pathway of the silkworm (Douglas, 257 2015). We hypothesized that Escherichia and Staphylococcus may also be involved in the 258 immunoreaction of L. invasa. Functions have been suggested for some of the other bacterial 259 genera detected in this study. The Enterobacteriaceae that are associated with insects help with 260 digestion, the detoxification of toxic substances, and resistance to pathogens and enhance the 261 adaptability of the host (Anand et al., 2010). Adding Enterobacter to feed extended the life span 262 of Mediterranean flies (Behar et al., 2005, 2008). Similarly, Enterobacteriaceae (Hongoh \& 263 Ishikawa, 2000) and Acinetobacter (Broderick et al., 2004) facilitated carbon-nitrogen 264 metabolism and accelerated the growth and development of host insects; e.g., the Acinetobacter 265 belonging to termites have a nitrogen-transforming function according to Warnecke's (2007) 266 research. Some bacteria associated with immunization were also discovered in L. invasa, such as 267 Lactobacillus. Lactobacillus had some positive effects on insect resistance (Xia et al., 2013). In 268 addition, Bacillales were also detected in this study and may be insect pathogens, such as 269 Bacillus thuringiensis and Bacillus cereus (Broderick et al., 2004; Raymond et al., 2010; Song et 270 al., 2014). In contrast, some Bacillus in termites might be involved in the degradation of 
271 cellulose and hemicellulose (Konig, 2006). In this study, Bacillales were detected in both sexes, 272 and their specific functions require further study. Nevertheless, Acinetobacter was detected in $L$. 273 invasa, and previous research showed that Acinetobacter produces an antiviral compound that 274 inhibits tobacco mosaic virus (Lee et al., 2009). Moreover, members of Bacteroidetes specialize 275 in the degradation of complex organic matter, including lignocellulosic compounds (Yuki et al., 276 2015). Bacteroidetes are also involved in the decomposition and metabolism of polysaccharides

277 (Xu et al., 2003; Sonnenburg et al., 2010), which are beneficial for host absorption and digestion 278 (Liu et al., 2011). In addition, Bacteroidetes also include some Azotobacter, such as 279 Azobacteroides pseudotrichonympha, which can provide the host with amino acids for nutrition 280 (Doda et al., 2009; Desai \& Brune, 2012). Bacteroidetes involved in the degradation and 281 fermentation of phytomass could influence the nutrient absorption of L. invasa, but further 282 studies are needed. Many other groups of bacteria with undefined functions were detected in $L$. 283 invasa for the first time in this study. Better knowledge of the bacteria associated with L. invasa 284 will allow researchers to investigate their role in host biology.

285 A sequence similarity search revealed that Rhizobium was the dominant bacterium in male 286 adults (Fig. 2, Table 3). Rhizobium produces a variety of enzymes with cellulose- and pectin287 hydrolyzing activities that can hydrolyze the glycoside skeleton of the plant cell wall and play a 288 very important role in the symbiosis between Rhizobium and leguminous plants (Robledo et al., 289 2008; Huang et al., 2018). Rhizobium is an endosymbiont detected in the gut of some 290 phytophagous insects and can help the host synthesize nitrogen-containing substances that are 291 lacking in food (Russell et al., 2009).

292 Rickettsia (with an abundance of 93.67\%) was the dominant bacterial genus present in 293 female adults (Fig. 2, Table 3). Rickettsia is a maternally inherited intracellular bacterium in a 294 wide range of arthropods and is capable of controlling populations by reproductive manipulation, 295 such as parthenogenesis inducing (PI) (Hagimori et al., 2006; Adachi-Hagimori et al., 2008; 296 Giorgini et al., 2010) and male killing (MK) (Lawson et al., 2001; Schulenburg et al., 2001; 297 Majerus \& Maherus, 2010). During female gamete formation in Rickettsia-carrying 298 Neochrysocharis formosa, meiotic cells underwent only one equatorial division, and meiotic 299 recombination was absent, which demonstrated that Rickettsia could induce parthenogenesis by 300 changing the meiosis of wasps (Adachi-Hagimori et al., 2008). Rickettsia also induced male 301 embryo death in Adalia bipunctata and A. decempunctata (Hurst GDD et al., 1993, 1996; 
302 Werren JH et al., 1994). Moreover, Rickettsia affects the fitness of the host and protects it

303 against adverse environmental conditions (Oliver et al., 2003; Sakurai et al., 2005; Chiel et al.,

304 2009; Himler et al., 2011; Brumin et al., 2011). For instance, preadult development of the

305 Bemisia tabaci B-biotype was faster with Rickettsia infection than without (Chiel et al., 2009).

306 Himler et al. (2011) found that Rickettsia-carrying whiteflies produced more offspring,

307 developed faster, had a higher rate of survival to adulthood, and produced a larger proportion of

308 daughters than did uninfected whiteflies. Males have never been recorded in Italy, Tunisia and

309 Argentina, and rarely in Turkey (sex ratio 0-0.5\%) (Nugnes et al., 2015). These results show that

310 L. invasa reproduces by thelytokous parthenogenesis. In contrast, males appeared more

311 frequently in China, India and Thailand. In this study, the sex ratio was $7.2 \%$. In addition,

312 Nugnes et al. (2015) found that Rickettsia was located in reproductive tissues in females and

313 passed to the next generation via vertical transmission, representing a possible reason for

314 thelytokous parthenogenesis in L. invasa. Female L. invasa play an important role in invasion

315 and colonization (Zheng et al., 2014a). The results of the current investigation could explain why

316 the sex ratio in wasps is female-biased and support the hypothesis that Rickettsia can induce

317 thelytokous parthenogenesis in L. invasa. However, both explanations require further testing. In

318 addition, a low abundance of Rickettsia was present in males in this research. For Hymenoptera,

319 the dominant reproductive mode is arrhenotoky; that is, diploid females develop from fertilized

320 eggs, and haploid males develop from unfertilized eggs (van Wilgenburg et al., 2006). A

321 previous investigation suggested that Rickettsia could be passed to the offspring by vertical

322 transmission (Nugnes et al., 2015), and a threshold density of Rickettsia bacteria in eggs is

323 required to trigger the development of female embryos (Giorgini et al., 2001; 2010). Removing

324 Rickettsia by feeding antibiotics could lead to the production of more male offspring. Giorgini et

325 al. (2010) found that Rickettsia-infected Pnigalio soemius generated only female progeny, and

326 after $24 \mathrm{~h}$, when the Rickettsia was removed by $20 \mathrm{mg} / \mathrm{mL}$ rifampin, adults produced almost all

327 male offspring. Hagimori et al. (2006) declared that Rickettsia was related to the thelytokous

328 parthenogenesis of $N$. formosa, a dominant parasite of leaf miners, and after removing Rickettsia

329 from the adults by feeding the adults tetracycline, female offspring without Rickettsia were

330 present. Therefore, future studies should clarify whether Rickettsia is involved in the

331 reproductive manipulation of L. invasa accomplished via feeding with antibiotics. Furthermore,

332 environmental factors could also influence the density of the bacteria, and endosymbiont 
333 densities and functions may change with space, time and season (Bordenstein \& Bordenstein,

334 2011; Nugnes et al., 2015). A previous study indicated that the sex ratio of the Chinese

335 population could change with temperature, presumably because the relationship between

336 Rickettsia strain and Chinese population is weaker than that of Western population, which could

337 be more susceptible to temperature (Zhu et al., 2014; Nugnes et al., 2015). In addition, another

338 plausible explanation may be the use of different host plants (the host of lineage A is $E$.

339 camaldulensis but in this research, it was DH201-2), which has been demonstrated in other

340 systems (Ferrari et al., 2007; Biere and Tack 2013). Therefore, it is also essential to compare the

341 differences in bacteria between L. invasa that parasitize different hosts.

\section{Conclusions}

343 The results of this study obtained by high-throughput revealed the bacterial diversity and

344 differences between sexes in L. invasa, suggesting an abundant endosymbiotic bacterial

345 community, and some bacteria were reported in L. invasa for the first time. Moreover, the males

346 harbored a more diverse bacterial community than did the females. The next research should

347 focus on the bacteria found in this study to identify their specific ecological functions and the

348 specific sex-based regulatory mechanism of Rickettsia occurrence in L. invasa.

\section{Acknowledgements}

350 The authors thank Prof. Yongqiang He for sharing his knowledge of bacteria, the State Key

351 Laboratory for Conservation and Utilization of Subtropical Agro-bioresources, and the members

352 of the Guangxi Key Laboratory of Forest Ecology and Conservation. 


\section{References}

354 Ahn JH, Hong IP, Bok JI, Kim BY, Song J, Weon HY. 2012. Pyrosequencing analysis of the

355

356

357

358

359

360

361

362

363

364

365

366

367

368

369

370

371

372

373

374

375

376

377

378

379

380

381

382

383 bacterial communities in the guts of Honey Bees Apis cerana and Apis mellifera in Korea. Journal of Microbiology 50(5): 735-745 DOI 10.1007/s12275-012-2188-0.

Adachi-Hagimori T, Miura K, Stouthamer R. 2008. A new cytogenetic mechanism for bacterial endosymbiont-induced parthenogenesis. Proceedings of the Royal Society BBiological Sciences 275(1652): 2667-2673 DOI 10.1098/rspb.2008.0792.

Anand AA, Vennison SJ, Sankar SG, Prabhu, DIG, Vasan PT, Raghuraman T, Geoffrey CJ, Vendan SE. 2010. Isolation and characterization of bacteria from the gut of Bombyx mori that degrade cellulose, xylan, pectin and starch and their impact on digestion. Journal of Insect Science 10: 1-20 DOI 10.1673/031.010.10701.

Behar A, Yuval B, Jurkevitch E. 2005. Enterobacteria-mediated nitrogen fixation in natural populations of the fruit fly Ceratitis capitata. Molecular Ecology 14(9): 2637-2643 DOI 10.1111/j.1365-294X.2005.02615.x.

Behar A, Yuval B, Jurkevitch E. 2008. Community structure of the Mediterranean fruit fly microbiota: seasonal and spatial sources of variation. Israel Journal of Ecology \& Evolution 54(2): 181-191 DOI 10.1080/15659801.2008.10639612.

Biere A, Tack AJM. 2013. Evolutionary adaptation in three-way interactions between plants, microbes and arthropods. Function Ecology 27: 646-660. DOI 10.1111/1365-2435.12096.

Bordenstein SR, Bordenstein SR. 2011. Temperature affects the tripartite interactions between bacteriophage WO, Wolbachia, and cytoplasmic incompatibility. PLoS ONE 6: e29106 DOI 10.1371/journal.pone.0029106.

Briones-Roblero CI, Rodriguez-Diaz R, Santiago-Cruz JA, Zuniga G, Rivera-Orduna FN. 2017. Degradation capacities of bacteria and yeasts isolated from the gut of Dendroctonus rhizophagus (Curculionidae: Scolytinae). Folia Microbiologica 62(1): 1-9 DOI 10.1007/s12223-016-0469-4.

Broderick NA, Raffa KF, Goodman RM, Handelsman J. 2004. Census of the bacterial community of the gypsy moth larval midgut by using culturing and culture-independent methods. Applied Environmental Microbiology 70(1): 293-300 DOI 10.1128/AEM.70.1.293-300.2004.

Brune A. 2014. Symbiotic digestion of lignocellulose in termite guts. Nature Reviews 
384

385

386

387

388

389

390

391

392

393

394

395

396

397

398

399

400

401

402

403

404

405

406

407

408

409

410

411

412

413

414

Microbiology 12(3): 168-180 DOI 10.1038/nrmicro3182.

Brumin M, Kontsedalov S, Ghanim M. 2011. Rickettsia influences thermotolerance in the whitefly Bemisia tabaci B biotype. Insect Science 18(1): 57-66 DOI 10.1111/j.17447917.2010.01396.x.

Chiel E, Inbar M, Mozes-Daube N, White JA, Hunter MS, Zchori-Fein E. 2009. Assessments of fitness effects by the facultative symbiont, Rickettsia, in the sweetpotato whitefly (Hemiptera: Aleyrodidae). Annals of the Entomological Society of America 102(3): 413-418 DOI 10.1603/008.102.0309.

Clark ME, Bailey-Jourdain C, Ferree PM, England SJ, Sullivan W, Windsor DM, Werren JH. 2008. Wolbachia modification of sperm does not always require residence within developing sperm. Heredity 101(5): 420-428 DOI 10.1038/hdy.2008.71.

Crotti E, Balloi A, Hamdi C, Sansonno L, Marzorati M, Gonella E, Favia G, Cherif A, Bandi C, Alma A, Daffonchio D, 2012. Microbial symbionts: a resource for the management of insect-related problems. Microbial Biotechnology 5(3): 307-317 DOI 10.1111/j.1751-7915.2011.00312.x.

Desai MS, Brune A. 2012. Bacteroidales ectosymbionts of gut flagellates shape the nitrogenfixing community in dry-wood termites. ISME Journal 6(7): 1302-1313 DOI 10.1038/ismej.2011.194.

Dillon RJ, Dillon VM. 2004. The gut bacteria of insects: nonpathogenic interactions. Annual Review of Entomology 49: 71-92 DOI 10.1146/annurev.ento.49.061802.123416.

Dittrich-Schröder G, Hoareau TB, Hurley BP, Wingfield MJ, Lawson S, Nahrung HF, Slippers B. 2018. Population genetic analyses of complex global insect invasions in managed landscapes: a Leptocybe invasa (Hymenoptera) case study. Biological Invasions 20(9): 2395-2420. DOI 10.1007/s10530-018-1709-0.

Doğanlar O. 2005. Occurrence of Leptocybe invasa Fisher \& La Salle, 2004 (Hymenoptera: Chalcidoidea: Eulophidae) on Eucalyptus camaldulensis in Turkey, with description of the male sex. Zoology in the Middle East 35: 112-114 DOI 10.1080/09397140.2005.10638116.

Douglas AE. 2015. Multiorganismal Insects: Diversity and Function of Resident Microorganisms. Annual Review of Entomology 60: 17-34 DOI 10.1146/annurev-ento010814-020822.

Engel P, Moran NA. 2013. The gut microbiota of insects-diversity in structure and function. 
415

416

417

418

419

420

421

422

423

424

425

426

427

428

429

430

431

432

433

434

435

436

437

438

439

440

441

442

443

444

445

FEMS Microbiology Reviews 37(5): 699-735 DOI 10.1111/1574-6976.12025.

Ferrari J, Scarborough CL, Godfray HCJ. 2007. Genetic variation in the effect of a facultative symbiont on host-plant use by pea aphids. Oecologia 153: 323-329 DOI $10.2307 / 40210868$.

Frago E, Dicke M, Godfray HCJ. 2012. Insect symbionts as hidden players in insect-plant interactions. Trends in Ecology \& Evolution 27(12): 705-711 DOI 10.1016/j.tree.2012.08.013.

Giorgini M. 2001. Induction of males in thelytokous populations of Encarsia meritoria and Encarsia protransvena: a systematic tool. BioControl 46(4): 427-438 DOI 10.1023/A:1014181431482.

Giorgini M, Bernardo U, Monti MM, Nappo AG, Gebiola M. 2010. Rickettsia symbionts cause parthenogenetic reproduction in the parasitoid wasp Pnigalio soemius (Hymenoptera: Eulophidae). Applied and Environmental Microbiology 76(8): 2589-2599 DOI 10.1128/AEM.03154-09.

Gualtieri L, Nugnes F, Nappo AG, Gebiola M, Bernardo U. 2017. Life inside a gall: closeness does not favour horizontal transmission of Rickettsia between a gall wasp and its parasitoid. FEMS Microbiology Ecology 93(7): fix087 DOI 10.1093/femsec/fix087.

Hagimori T, Abe Y, Date S, Miura K. 2006. The first finding of a Rickettsia bacterium associated with parthenogenesis induction among insects. Current Microbiology 52(2): 97101 DOI 10.1007/s00284-005-0092-0.

Hammer TJ, Bowers MD. 2015. Gut microbes may facilitate insect herbivory of chemically defended plants. Oecologia 179(1): 1-14 DOI 10.1007/s00442-015-3327-1.

Hurst GDD, Majerus MEN, Walker LE. 1993. The importance of cytoplasmic male killing elements in natural populations of the two spot ladybird, Adalia bipunctata (Linnaeus) (Coleoptera: Coccinellidae). Biological Journal of the Linnean Society 49(2): 195-202.

Hurst GDD, Walker LE, Majerus MEN. 1996. Bacterial infections of hemocytes associated with the maternally inherited male-killing trait in British populations of the two spot ladybird, Adalia bipunctata. Journal of Invertebrate Pathology 68(3): 286-292. DOI 10.1006/jipa.1996.0098.Himler AG, Adachi-Hagimori T, Bergen JE, Kozuch A, Kelly SE, Tabashnik BE, Chiel E, Duckworth VE, Dennehy TJ, Zchori-Fein E, Hunter MS. 2011. Rapid spread of a bacterial symbiont in an invasive whitefly is driven by fitness 
446

447

448

449

450

451

452

453

454

455

456

457

458

benefits and female bias. Science 332(6026): 254-256 DOI 10.1126/science.1199410.

Hongoh Y, Ishikawa H. 2000. Evolutionary studies on uricases of fungal endosymbionts of aphids and planthoppers. Journal of Molecular Evolution 51(3): 265-277 DOI $10.1007 / \mathrm{s} 002390010088$.

Huang MY, Ge XZ, Shi HL, Tong YG, Shi J. 2019. Prediction of Current and Future Potential Distributions of the Eucalyptus Pest Leptocybe invasa (Hymenoptera: Eulophidae) in China Using the CLIMEX Model. Pest management science DOI10.1002/ps.5408.

Huang XF, Chaparro JM, Reardon KF, Judd TM, Vivanco JM. 2016. Supplementing blends of sugars, amino acids, and secondary metabolites to the diet of Termites (Reticulitermes flavipes) drive distinct gut bacterial communities. Microbial Ecology 72(3): 497-502 DOI 10.1007/s00248-016-0792-y.

Huang ZY, Li J, Lu W, Zheng XL, Yang ZD. 2018. Parasitoids of the eucalyptus gall wasp Leptocybe spp.: a global review. Environmental Science and Pollution Research 25(30): 29983-29995 DOI 10.1007/s11356-018-3073-0.

Konig H. 2006. Bacillus species in the intestine of termites and other soil invertebrates. Journal of Applied Microbiology 101: 620-627 DOI 10.1111/j.1365-2672.2006.02914.x.

Kumari KN, Kulkarni H, Vastrad AS, Goud KB. 2010. Biology of eucalyptus gall wasp, Leptocybe invasa Fisher \& La Salle (Hymenoptera: Eulophidae). Karnataka Journal of Agricultural Sciences 23: 211-212.

Kurtz J, Wiesner A, Gotz P, Sauer KP. 2000. Gender differences and individual variation in the immune system of the scorpionfly Panorpa vulgaris (Insecta: Mecoptera). Development and Comparative Immunology 24(1): 1-12 DOI 10.1016/S0145-305X(99)00057-9.

Lawson ET, Mousseau TA, Klaper R, Hunter MD, Werren JH. 2001. Rickettsia associated with male-killing in a buprestid beetle. Heredity 86(4): 497-505 DOI 10.1046/j.13652540.2001.00848.x.

Le NH, Nahrung HF, Griffiths M, Lawson SA. 2018. Invasive Leptocybe spp. and their natural enemies: Global movement of an insect fauna on eucalypts. Biological Control 125: 7-14 DOI 10.1016/j.biocontrol.2018.06.004.

Lee JS, Lee KC, Kim KK, Hwang IC, Jang C, Kim NG, Yeo WH, Kim BS, Yu YM, Ahn JS. 2009. Acinetobacter antiviralis sp. nov., from Tobacco plant roots. Journal of Microbiology and Biotechnology 19(3): 250-256 DOI 10.4014/jmb.0901.083. 
477 Leulier F, Royet J. 2009. Maintaining immune homeostasis in fly gut. Nature Immunology 478 10(9): 936-938 DOI 10.1038/ni0909-936.

479 Liu N, Yan X, Zhang ML, Xie L, Wang QA, Huang YP, Zhou XG, Wang SY, Zhou ZH. 480 2011. Microbiome of fungus-growing termites: a new reservoir for lignocellulase genes. Applied and Environmental Microbiology 77(1): 48-56 DOI 10.1128/AEM.01521-10.

Lukasik P, Guo H, Van Asch M, Ferrari J, Godfray HCJ. 2013a. Protection against a fungal pathogen conferred by the aphid facultative endosymbionts Rickettsia and Spiroplasma is expressed in multiple host genotypes and species and is not influenced by co-infection with another symbiont. Journal of Evolutionary Biology 26(12): 2654-2661.

486

487

488

489

490

491

492

493

494

495

496

497

498

499

500

501

502

503

504

505

506

507

Lukasik, P, Van Asch M, Guo HF, Ferrari J, Godfray HCJ. 2013b. Unrelated facultative endosymbionts protect aphids against a fungal pathogen. Ecology Letters 16(2): 214-218 DOI 10.1111/ele.12031.

Majerus TMO, Majerus MEN. 2010. Discovery and identification of a male-killing agent in the Japanese ladybird Propylea japonica (Coleoptera: Coccinellidae). BMC Evolution Biology 10: 37 DOI 10.1186/1471-2148-10-37.Makonde HM, Boga HI, Osiemo Z, Mwirichia R, Mackenzie LM, Goker M, Klenk HP. 2013. 16S-rRNA-based analysis of bacterial diversity in the gut of fungus-cultivating termites (Microtermes and Odontotermes species). Antonie van Leeuwenhoek International Journal of General and Molecular Microbiology 104(5): 869-883 DOI 10.1007/s10482-013-0001-7.

Mendel Z, Protasov A, Fisher N, La Salle J. 2004. Taxonomy and biology of Leptocybe invasa gen. \& sp. n. (Hymenoptera: Eulophidae), an invasive gall inducer on Eucalyptus. Australian Journal of Entomology 43: 101-113 DOI 10.1111/j.1440-6055.2003.00393.x.

Minard G, Mavingui P, Moro CV. 2013. Diversity and function of bacterial microbiota in the mosquito holobiont. Parasites \& Vectors 6: 146 DOI 10.1186/1756-3305-6-146.

Miyata R, Noda N, Tamaki H, Kinjyo K, Aoyagi H, Uchiyama H, Tanaka H. 2007. Influence of Feed Components on Symbiotic Bacterial Community Structure in the Gut of the Wood-Feeding Higher Termite Nasutitermes takasagoensis. Bioscience Biotechnology and Biochenmistry 71(5): 1244-1251 DOI 10.1271/bbb.60672.

Mohr KI, Tebbe CC. 2006. Diversity and phylotype consistency of bacteria in the guts of three bee species (Apoidea) at an oilseed rape field. Environmental Microbiology 8(2): 258-272 DOI 10.1111/j.1462-2920.2005.00893.x. 
508 Moran NA. 2007. Symbiosis as an adaptive process and source of phenotypic complexity.

509

510

511

512

513

514

515

516

517

518

519

520

521

522

523

524

525

526

527

528

529

530

531

532

533

534

535

536

537

538

Proceedings of the National Academy of Sciences of the United States of America 104: 8627-8633 DOI 10.1073/pnas.0611659104.

Moran NA, McCutcheon JP, Nakabachi A. 2008. Genomics and evolution of heritable bacterial symbionts. Annual Review of Genetics 42: 165-190 DOI 10.1146/annurev.genet.41.110306.130119.

Moran NA. 2016. Insights into the roles of bacterial symbionts within flagellates of termite guts. Environmental Microbiology Reports 8(5): 559-559 DOI 10.1111/1758-2229.12471.

Moya A, Pereto J, Gil R, Latorre A. 2008. Learning how to live together: genomic insights into prokaryote-animal symbioses. Nature Review of Genetics 9(3): 218-229 DOI $10.1038 / \mathrm{nrg} 2319$.

Noda S, Hongoh Y, Sato T, Ohkuma M. 2009. Complex coevolutionary history of symbiotic Bacteroidades bacteria of various protist in the gut of termites. BMC Evolutionary Biology 9: 1-12 DOI: 10.1186/1471-2148-9-158.

Nugnes F, Gebiola M, Monti MM, Gualtieri L, Giorgini M, Wang JG, Bernardo U. 2015. Genetic diversity of the invasive gall wasp Leptocybe invasa (Hymenoptera: Eulophidae) and of its Rickettsia endosymbiont, and associated sex-ratio differences. PLoS One 10(5): e0124660 DOI 10.1371/journal.pone.0124660.

Oliver KM, Russell JA, Moran NA, Hunter MS. 2003. Facultative bacterial symbionts in aphids confer resistance to parasitic wasps. Proceedings of the National Academy of Sciences of the United States of America 100(4): 1803-1807 DOI 10.1073/pnas.0335320100.

Oliver KM, Degnan PH, Burke GR, Moran NA. 2010. Facultative symbionts in aphids and the horizontal transfer of ecologically important traits. Annual Review of Entomology 55: 247-266 DOI 10.1146/annurev-ento-112408-085305.

Praet J, Parmentier A, Schmid-Hempel R, Meeus I, Smagghe G, Vandamme P. 2018. Large-scale cultivation of the bumblebee gut microbiota reveals an underestimated bacterial species diversity capable of pathogen inhibition. Environmental Microbiology 20(1): 214227 DOI: $10.1111 / 1462-2920.13973$.

Raymond B, Johnston PR, Nielsen LC, Lereclus D, Crickmore N, Lereclus D, Crickmore N. 2010. Bacillus thuringiensis: an impotent pathogen? Trends in Microbiology 18(5): 189-194 DOI 10.1016/j.tim.2010.02.006. 
539

540

541

542

543

544

545

546

547

548

549

550

551

552

553

554

555

556

557

558

559

560

561

562

563

564

565

566

567

568

569

Robledo M, Jimenez-Zurdo JI, Velazquez E, Trujillo ME, Zurdo-Pineiro JL, RamirezBahena MH, Ramos B, Diaz-Minguez JM, Dazzo F, Martinez-Molina E, Mateos PF. 2008. Rhizobium cellulase CelC 2 is essential for primary symbiotic infection of legume host roots. Proceedings of the National Academy of Sciences of the United States of America 105(19): 7064-7069 DOI 10.1073/pnas.0802547105.

Russell JA, Moreau CS, Goldman-Huertas B, Fujiwara M, Lohman DJ, Pierce NE. 2009. Bacterial gut symbionts are tightly linked with the evolution of herbivory in ants. $\mathrm{P}$ Proceedings of the National Academy of Sciences of the United States of America 106(50): 21236-21241 DOI 10.1073/pnas.0907926106.

Sakurai M, Koga R, Tsuchida T, Meng XY, Fukatsu T. 2005. Rickettsia symbiont in the pea aphid Acyrthosiphon pisum: novel cellular tropism, effect on host fitness, and interaction with the essential symbiont Buchnera. Applied and Environmental Microbiology 71(7): 4069-4075 DOI 10.1128/AEM.71.7.4069-4075.2005.

Schulenburg JHGV, Habig M, Sloggett JJ, Webberley KM, Bertrand D, Hurst GDD, Majerus MEN. 2001. Incidence of male-killing Rickettsia spp. ( $\alpha$-Proteobacteria) in the ten-spot ladybird beetle Adalia decempunctata L. (Coleoptera: Coccinellidae). Applied Environmental Microbiology 67(1): 270-277 DOI 10.1128/AEM.67.1.270-277.2001.

Shi WB, Syrenne R, Sun JZ, Yuan JS. 2010. Molecular approaches to study the insect gut symbiotic microbiota at the 'omics' age. Insect Science 17(3): 199-219. DOI 10.1111/j.1744-7917.2010.01340.x.

Song F, Peng Q, Brillard J, Lereclus D, LeRoux CN. 2014. An insect gut environment reveals the induction of a new sugar-phosphate sensor system in Bacillus cereus. Gut Microbes 5(1): 58-63 DOI 10.4161/gmic.27902.

Sonnenburg ED, Zheng H, Joglekar P, Higginbottom SK, Firbank SJ, Bolam DN, Sonnenburg JL. 2010. Specificity of polysaccharide use in intestinal Bacteroides species determines diet-induced microbiota alterations. Cell 141(7): 1241-1252 DOI 10.1016/j.cell.2010.05.005.

Tang X, Adler PH, Vogel H, Ping LY. 2012. Gender-specific bacterial composition of black flies (Diptera: Simuliidae). FEMS Microbiology Ecology 80(3): 659-670 DOI 10.1111/j.1574-6941.2012.01335.x.

van Wilgenburg E, Driessen G, Beukeboom L W. 2006. Single locus complementary sex 
570

571

572

573

574

575

576

577

578

579

580

581

582

583

584

585

586

587

588

589

590

591

592

593

594

595

596

597

598

599

600

determination in Hymenoptera: an "unintelligent" design? Frontiers in Zoology 3(1): 1-15 DOI 10.1186/1742-9994-3-1.

Wang SB, Ghosh AK, Bongio N, Stebbings KA, Lampe DJ, Jacobs-Lorena M. 2012.

Fighting malaria with engineered symbiotic bacteria from vector mosquitoes. Proceedings of the National Academy of Sciences of the United States of Ameica 109(31): 12734-12739. DOI 10.1073/pnas.1204158109.

Wang RR, Hu Y, Yang ZD, Guo CH, Zhu LH, Zheng XL, Yu SZ. 2018. Isolation, identification and diversity of culturable bacteria in female adults of Leptocybe invasa Fisher \& La Salle. Journal of Southern Agriculture 49(12): 2432-2439. (in Chinese with English abstract)

Warnecke F, Luginbuhl P, Ivanova N, Ghassemian M, Richardson TH, Stege JT, Cayouette M, McHardy AC, Djordjevic G, Aboushadi N, Sorek R, Tringe SG, Podar M, Martin HG, Kunin V, Dalevi D, Madejska J, Kirton E, Platt D, Szeto E, Salamov A, Barry K, Mikhailova N, Kyrpides NC, Matson EG, Ottesen EA, Zhang X, Hernandez M, Murillo C, Acosta LG, Rigoutsos I, Tamayo G, Green BD, Chang C, Rubin EM, Mathur EJ, Robertson DE, Hugenholtz P, Leadbetter JR. 2007. Metagenomic and functional analysis of hindgut microbiota of a wood-feeding higher termite. Nature 450(7169): 560-565 DOI 10.1038/nature06269.

Werren JH, Hurst GDD, Zhang W, Breeuwer JA, Stouthamer R, Majerus ME. 1994. Rickettsial relative associated with male killing in the ladybird beetle (Adalia bipunctata). Journal of Bacteriology, 176(2): 388-394.

Xia XF, Zheng DD, Zhong HZ, Qin BC, Gurr GM, Vasseur L, Lin HL, Bai JL, He WY, You MS. 2013. DNA sequencing reveals the midgut microbiota of diamondback moth, Plutella xylostella (L.) and a possible relationship with insecticide resistance. PLoS ONE 8(7): e68852 DOI 10.1371/journal.pone.0068852.

Xiang H, Xie L, Zhang J, Long YH, Liu N, Huang YP, Wang Q. 2012. Intracolonial difference in gut bacterial community between worker and soldier castes of Coptotermes formosanus. Insect Science 19(1): 86-95 DOI 10.1111/j.1744-7917.2011.01435.x.

Xu J, Bjursell MK, Himrod J, Deng S, Carmichael LK, Chiang HC, Hooper LV, Gordon JI. 2003. A genomic view of the human-Bacteroides thetaiotaomicron symbiosis. Science 299(5615): 2074-2076 DOI 10.1126/science.1080029. 
601 Xu LT, Lu M, Xu DD, Chen L, Sun JH. 2016. Sexual variation of bacterial microbiota of 602 Dendroctonus valens guts and frass in relation to verbenone production. Journal of Insect Physiology 95: 110-117 DOI 10.1016/j.jinsphys.2016.09.014. 2015. Dominant ectosymbiotic bacteria of cellulolytic protists in the termite gut also have the potential to digest lignocellulose. Environmental Microbiology 17(12): 4942-4953 DOI 10.1111/1462-2920.12945.

Zheng XL, Li J, Yang ZD, Xian ZH, Wei JG, Lei CL, Wang XP, Lu W. 2014a. A review of invasive biology, prevalence and management of Leptocybe invasa Fisher \& La Salle (Hymenoptera: Eulophidae: Tetrastichinae). African Entomology 22(1): 68-79 DOI 10.4001/003.022.0133.

Zheng XL, Yang ZD, Li J, Xian ZH, Yang J, Liu JY, Su S, Wang XL, Lu W. 2014b. Rapid identification of both sexes of Leptocybe invasa Fisher \& La Salle (Hymenoptera:

Eulophidae: Tetrastichinae): a morphological perspective. African Entomology 22(3): 643650 DOI 10.4001/003.022.0326.

Zheng XY, Zhang DJ, Li YJ, Yang C, Wu Y, Liang X, Liang YK, Pan XL, Hu LC, Sun Q, Wang XH, Wei YY, Zhu J, Qian W, Yan ZQ, Parker AG, Gilles JRL, Bourtzis K, Bouyer J, Tang MX, Zheng B, Yu JS, Liu JL, Zhuang JJ, Hu ZG, Zhang MC, Gong JT, Hong XY, Zhang ZB, Lin LF, Liu QY, Hu ZY, Wu ZD, Baton LA, Hoffmann AA, Xi ZY. 2019. Incompatible and sterile insect techniques combined eliminate mosquitoes. Nature DOI 10.1038/s41586-019-1407-9.

Zhu FL, Ren SX, Qiu BL, Wu JH. 2015. Effect of temperature on life table parameters of Leptocybe invasa (Hymenoptera: Eulophidae). Austral Entomology 54: 71-78. DOI 10.1111/aen.12094.

Zouache K, Raharimalala FN, Raquin V, Tran-Van V, Raveloson LHR, Ravelonandro P, Mavingui P. 2011. Bacterial diversity of field-caught mosquitoes, Aedes albopictus and Aedes aegypti, from different geographic regions of Madagascar. FEMS Microbiology Ecology 75(3): 377-389 DOI 10.1111/j.1574-6941.2010.01012.x. 
Figure 1

Venn diagram of OTU distribution in Leptocybe invasa female and male adults.

Numbers within compartments indicate OTU counts of according to mathematical sets.

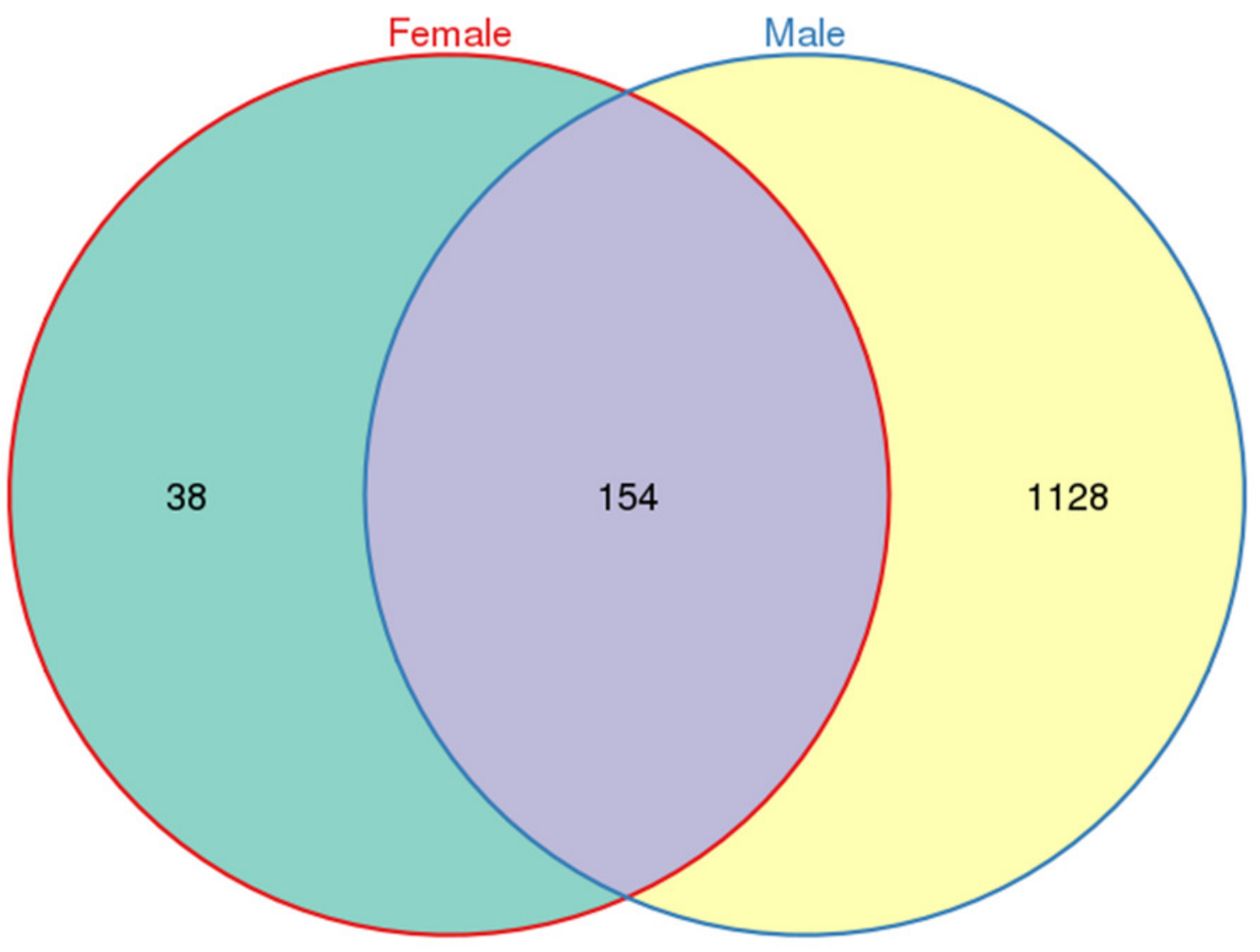




\section{Figure 2}

Relative abundance of top 10 bacteria at the levels of phylum (A), class (B), order (C), family (D) and genu (E) in females and males of Leptocybe invasa.
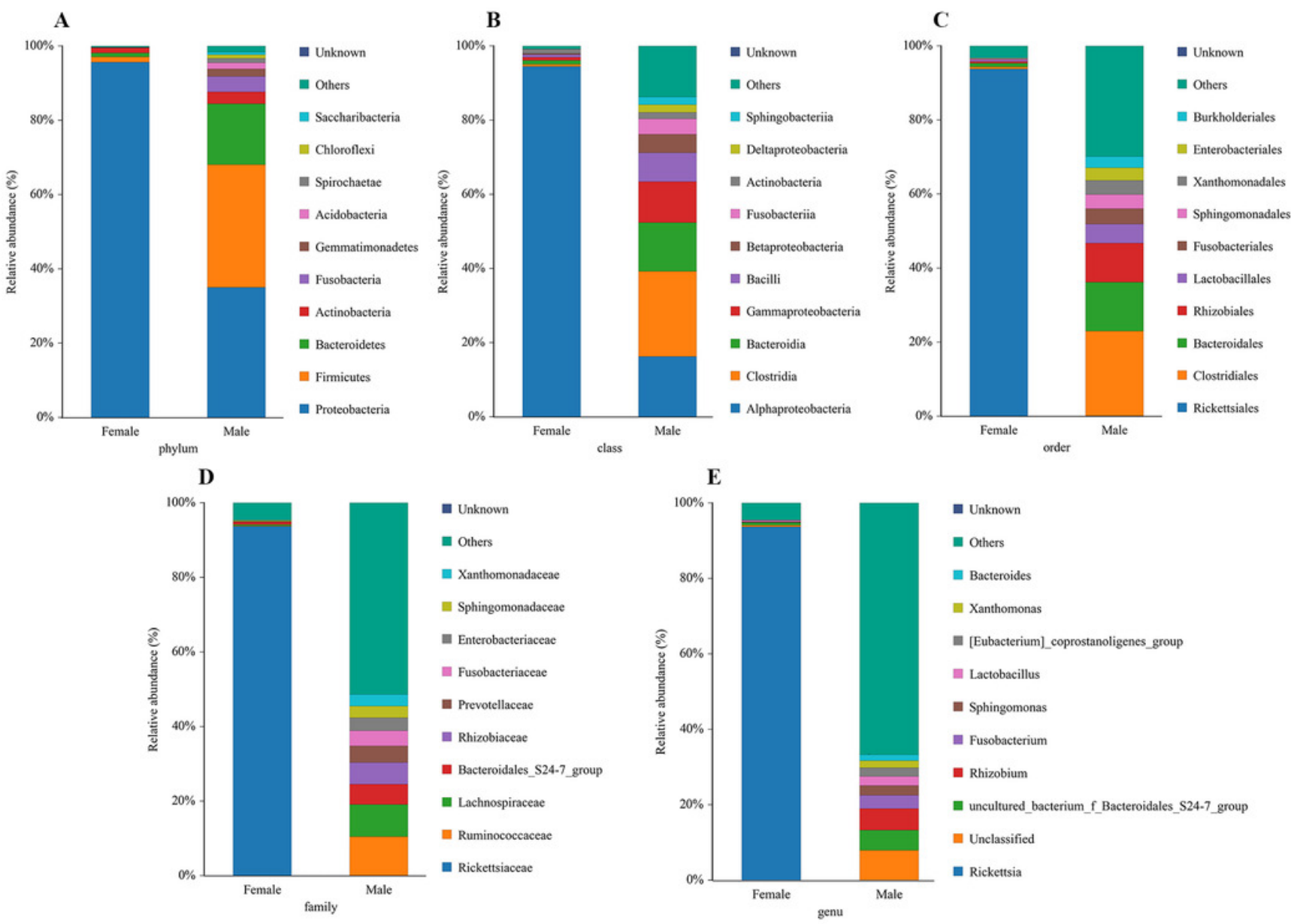
Figure 3

Phylogenetic tree of different Leptocybe invasa populations based on COI sequences.

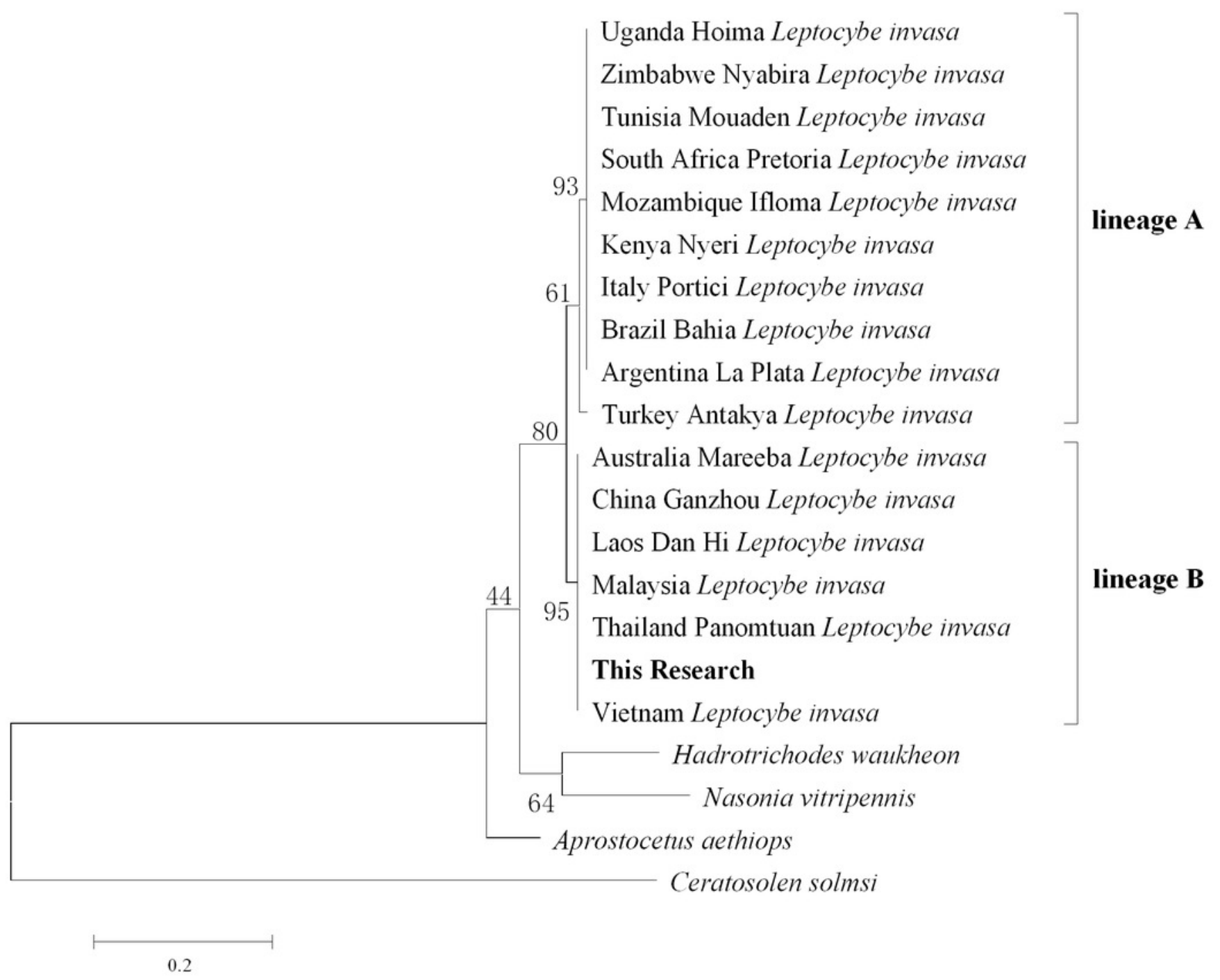




\section{Figure 4}

\section{Phylogenetic analysis of different Rickettsia groups based on their 16S rRNA sequences.}

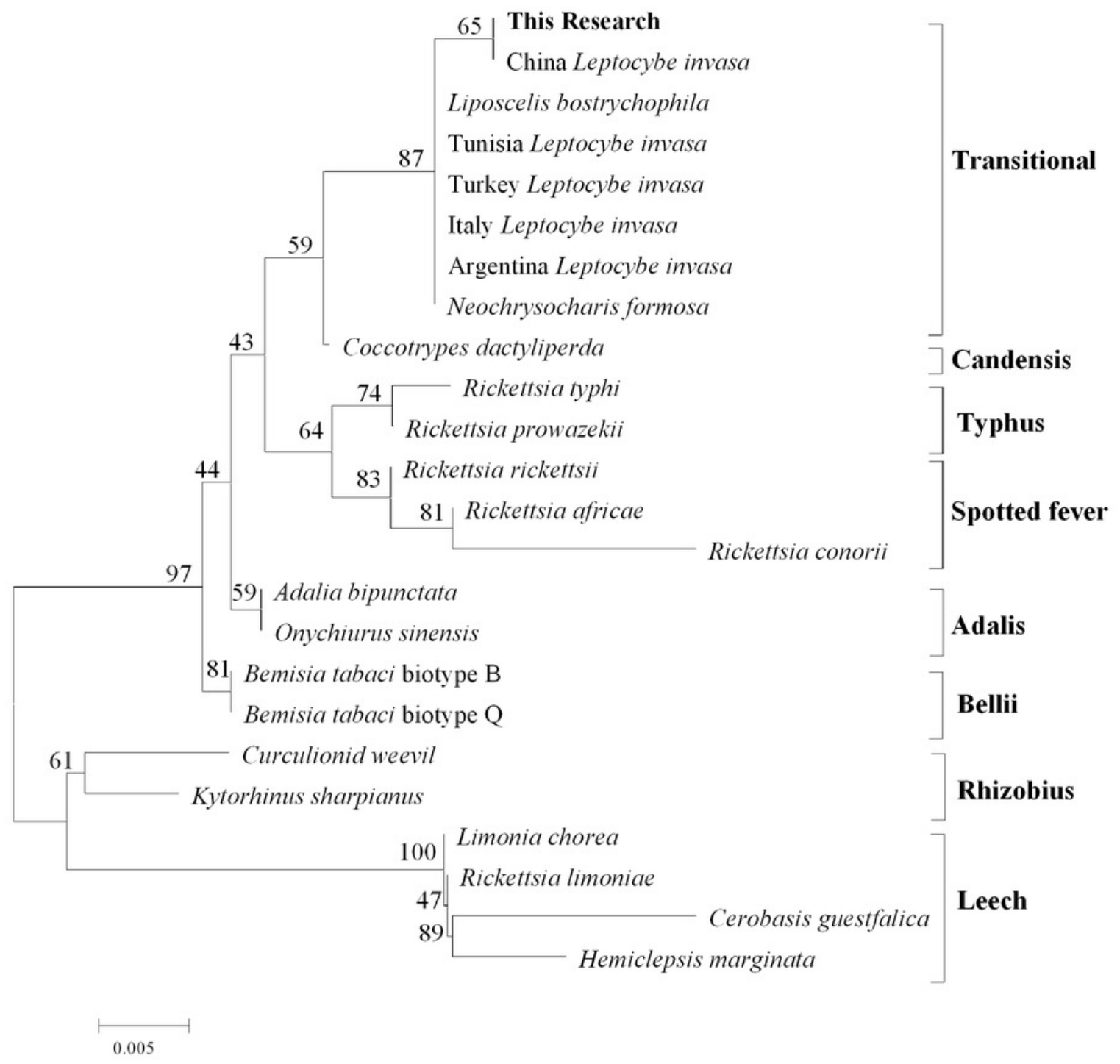




\section{Table 1 (on next page)}

Statistics of alpha diversity indices of the bacteria in female and male adults of Leptocybe invasa. 
1 Table 1:

2 Statistics of alpha diversity indices of the bacteria in female and male adults of Leptocybe invasa

\begin{tabular}{llllll}
\hline Sample & ACE & Chao1 & Simpson & Shannon & Coverage \\
\hline Female & 212.84 & 229.50 & 0.85 & 0.59 & 1.00 \\
Male & 1282.28 & 1282.00 & 0.01 & 6.13 & 1.00 \\
\hline
\end{tabular}

3 


\section{Table 2 (on next page)}

Basic composition of the bacterial colonies in female and male adults of Leptocybe invasa. 
1 Table 2:

2 Basic composition of the bacterial colonies in female and male adults of Leptocybe invasa

\begin{tabular}{llllll}
\hline Sample & Phylum & Class & Order & Family & Genus \\
\hline Female & 10 & 26 & 44 & 76 & 122 \\
Male & 24 & 69 & 127 & 238 & 487 \\
Female-specific & 0 & 2 & 3 & 7 & 14 \\
Male-specific & 14 & 45 & 86 & 169 & 379 \\
Sex-in common & 10 & 24 & 41 & 69 & 108 \\
Total & 24 & 71 & 130 & 245 & 501 \\
\hline
\end{tabular}

3

4 


\section{Table 3 (on next page)}

Relative abundance of dominate bacteria at the levels of genus in female and male adults of Leptocybe invasa. 
1 Table 3:

2 Relative abundance of dominate bacteria at the levels of genus in female and male adults of

3 Leptocybe invasa

\begin{tabular}{lll}
\hline Genus & Female (\%) & Male (\%) \\
\hline Rickettsia & 93.67 & 0.04 \\
uncultured_bacterium_f_Bacteroidales_S24-7_group & 0.71 & 5.37 \\
Lactobacillus & 0.31 & 2.38 \\
Sphingomonas & 0.25 & 2.62 \\
Bacteroides & 0.11 & 1.65 \\
Fusobacterium & 0.04 & 3.49 \\
[Eubacterium]_coprostanoligenes_group & 0 & 2.34 \\
Rhizobium & 0 & 5.73 \\
Unknown & 0 & 0.01 \\
Xanthomonas & 0 & 1.83 \\
Others & 4.48 & 66.68 \\
Unclassified & 0.44 & 7.86 \\
\hline
\end{tabular}

4 